\title{
Management of Village Common Forests in the Chittagong Hill Tracts of Bangladesh: Historical Background and Current Issues in Terms of Sustainability
}

\author{
Mohammed Jashimuddin ${ }^{1,2}$, Makoto Inoue ${ }^{1}$ \\ ${ }^{1}$ Department of Global Agricultural Sciences, Graduate School of Agricultural and Life Sciences, \\ University of Tokyo, Tokyo, Japan \\ ${ }^{2}$ Institute of Forestry and Environmental Sciences, University of Chittagong, Chittagong, Bangladesh \\ Email: mjashimuddin2001@yahoo.co.uk
}

Received December $20^{\text {th }}, 2011$; revised January $19^{\text {th }}, 2012$; accepted February $15^{\text {th }}, 2012$

\begin{abstract}
This study was conducted to investigate the historical management system of village common forests (VCF) in the Chittagong Hill Tracts (CHT) of Bangladesh and observe the current issues related to their sustainability. The study on historical context was based on secondary information to establish the linkages of VCF development and management in the CHT. Field visits to four VCF in the Bandarban Hill Districts were also conducted to cross check the information collected from secondary sources to observe the current status and management pattern of these VCF through semi-structured interviews, group discussion, key-informant interviews and biodiversity assessment. VCF in the CHT undoubtedly play an important role in biodiversity conservation and as well as supporting daily necessities of the community people. We found that VCF still are the source of fuel wood, herbs, roots, bamboo shoots, wild fruits, vines or leaves for cooking or medicinal use necessary to sustain the lives of the indigenous communities in the CHT. Field visits to different VCF show that the VCF are necessarily small in size (57 ha) and around 108 families are dependent on these community managed village forests. A total of 163 plant species from 60 families were also recorded from these VCF including some rare plant and animal species which are not usually found in the reserve forests and the un-classed state forests due to continued deforestation and land degradation. However, population pressure combined with improved marketing facilities, ignorance, over exploitation, personal greed, tenure insecurity, faulty government policies regarding settlement of land and breakdown of the traditional systems exerting pressures on these VCF and the overall condition of these important biodiversity rich areas are degrading or shrinking in size and number gradually. Recognizing the traditional and customary resource rights of the indigenous communities in the CHT, acknowledging resource management system, providing tenure security, encouraging communities through legal and financial incentives in protecting these VCF or any other state owned forest areas solely for the conservation of biodiversity following an intensive management plan, resolving long lasting land related conflicts, and at the same time upholding the spirit of CHT Peace Accord 1997 could be important policy tools for the sustainability of these VCF in the CHT. Lessons learned from this study will be useful in formulating effective policies for community based forest management in Bangladesh and other developing countries.
\end{abstract}

Keywords: Common Forests; Community-Based Forest Management; Village Common Forests; Chittagong Hill Tracts; Bangladesh

\section{Introduction}

Forests are the source of livelihoods for hundreds of millions of people worldwide (CIFOR, 2011) whose beneficial roles are clearly acknowledged in many ancient and religious texts of the South Asian countries (Biswas, 1992). During economic crisis forests provide employment and livelihoods for a large proportion of the population, especially in developing countries, and often act as an economic safety net in times of need (FRA, 2010). Since time immemorial forest has been used by the tribal population for hunting ground, food gathering, swidden cultivation, grazing ground, charcoal making and minor forest produce collection including medicinal or herbal produce as major means of livelihood (Mahapatra, 1997; Roy, 2000; Roy, 2002; Halim \& Roy, 2006; Chowdhury, 2008). In the same way, forest has always played a vital role in the economy of the tribes in
Bangladesh, whose religious, cultural and economic activities depend on it (Rasul, 2007; Miah \& Chowdhury, 2004; Chowdhury \& Miah, 2003; Roy, 2000; Baten et al., 2010). While forests have always played an important role in human history, their rational management became a priority societal concern in the 1980s in both developed and developing countries (Biswas, 1992). Faced with increasing rates of deforestation, and the attendant problems of loss of biodiversity and other socioenvironmental costs, the issue of conservation and rational management of forests became an important item in the agenda of numerous national and international forums. The issue of climate change occupies a prominent position in international discussions, and forests have a particular role to play in the global response (FAO, 2011). The world is now in a stage of transition, triggered by environmental crises and vulnerabilities where 
maintaining sustainability in all development initiatives is crucial, not only for scientist and decision makers, but for long term survival of the earth system (Azam \& Sarker, 2011). Currently, the major thrust of the international community is to maintain biodiversity and forest health, ensure adequate productivity and protect the socio-economic functions of forest resources (Muhammed, Koike, \& Haque, 2008). Global initiatives for environmental resource management have also led to widespread programs for the devolution of natural resource management arrangements to local communities (Baumann, 2002; Behera \& Engel, 2006). These initiatives are based on the belief that community based natural resource management can build on traditional practices and knowledge in providing sustainable and locally specific management (Baumann, 2002). Principle 22 of the Rio Declaration at Rio de Janeiro in 1992 on Environment and Development also emphasized the need to recognize the role of indigenous people and their traditional knowledge systems in environmental protection and sustainable development.

In developing countries, forest and conservation policies have traditionally been characterized by general distrust of local people's ability to manage the natural resources on which they depend (Heltberg, 2001). However, recent studies show there is growing evidence that local community-based entities are as good, and often better, managers of forests than federal, regional and local governments (White \& Martin, 2002). Some study also contradict with Hardin's (1968) well known postulation, the Tragedy of the Commons, showing examples of successful common property regimes where users were able to restrict access to the resources and establish rules among themselves for its sustainable use (Feeny et al., 1990; Berkes et al., 1989; Rasul \& Thapa, 2005; Rasul \& Karki, 2006). Realizing the shortcomings of traditional top-down state forest and biodiversity management, developing countries are increasingly embracing participatory approaches to natural resource management (Heltberg, 2001). Around the world, there are an increasing number of studies that highlight successes in community-based forest management (Stocks, McMahan, \& Taber, 2007; Ruiz-Pérez et al., 2005). The collective actions of local communities have resulted in regeneration of good forest stock leading to revival of the lost biodiversity (Panigrahi, 2006). Now, nearly everywhere, both the resources and the common property systems are facing increasing pressures as populations grow and the economic and political environment changes. In some cases common property systems have been legislated out of existence, and in other cases local management mechanisms have weakened or disappeared gradually as communities have evolved and changed (McKean \& Ostrom, 1995; Arnold, 1998). Nevertheless, communal management has remained as important option for a great number of communities, and continues to be a potential strategy for the conservation and sustainable use of large parts of the world's forests (Arnold, 1998).

The Chittagong Hill Tracts (CHT) in Bangladesh supports almost $80 \%$ of the country's total biodiversity (Nishat \& Biswas, 2005), and is inhibited by people from 12 ethnic groups (Rasul, 2007; Rasul \& Thapa, 2006; Miah \& Chowdhury, 2004; Chowdhury \& Miah, 2003; van Schendel, Mey, \& Dewan, 2001; Roy, 2000; Nasreen \& Togawa, 2002) who depend largely on forest commons to fulfill their basic subsistence requirements and cash income (Rasul \& Karki, 2006; Rasul, 2007; Miah \& Chowdhury, 2004). The wide variety of plants and animals of the hill forests has supported the livelihoods of the hill people including dwelling, food, clothing, health care, festivals and other activities. For many centuries, the indigenous communities have managed the forests in a sustainable manner by keeping the rotation of their shifting cultivation long enough (1520 years) (Rasul \& Thapa, 2003; Roy, 1998; Tiwari, 2003). Population pressure, over cropping and soil erosion, indiscriminate illegal logging in forest areas and lack of suitable land, shifting cultivators nowadays are forced to use a shortened fallow period (3 - 4 years) (Rasul \& Thapa, 2003; Tiwari, 2003; Roy \& Halim, 2002; Roy, 2000; Rahman et al., 2007) resulting in falling yields and drastic loss of forest coverage leading to land degradation (Nath \& Inoue, 2008a; Roy, 1998). Although indigenous people have widely been blamed for degrading South Asia's mountain forest resources through the practice of shifting cultivation, yet some studies have revealed that they used forest resources in a sustainable way for centuries (Roy, 1998, 2002; Roy, 2000) until external intervenetion (Rasul, 2007; Chakma et al., undated) such as displacement and deforestation (Tiwari, 2003). Shifting cultivation, which long provided the subsistence requirements of a large number of people in the mountains of South and Southeast Asia under a situation of low population, has been shown to be an environmentally and economically unsuitable practice (Rasul \& Thapa, 2003; Rasul, Thapa, \& Zoebisch, 2004), and jhumias or jhummas (shifting cultivators) face a food shortage of two to six months in a year (Nath, Inoue, \& Chakma, 2005a; Jamaluddin et al., 2010; Nath \& Inoue 2009; Rasul, Thapa, \& Zoebisch, 2004). A rapid rise in population by endemic means and by in-migration of plains people, the construction of development infrastructures (e.g., hydroelectric projects), and government policies on expansion of reserve and protected forests have made the jhum farming vulnerable (Nath, Inoue, \& Hla Myant, 2005 b). Efforts have been made throughout the region to replace it with more productive and sustainable land-use systems resulting in mixed experiences. Shifting cultivation has been almost entirely changed to subsistence type permanent cultivation integrated with livestock in Nepal, considerable changes have taken place in Thailand, Indonesia and Malaysia in the form of semi-commercialized permanent cultivation using external inputs and mechanized means of cultivation (Rasul \& Thapa, 2003; Rasul, Thapa, \& Zoebisch, 2004; Rahman, Rahman, \& Sunderland, 2011). However, shifting cultivation is still being widely practiced in the mountains of Bangladesh, Laos, north-eastern India, and outer islands of Indonesia (Rasul \& Thapa, 2003).

Village common forests (VCF), managed by indigenous communities, are essentially repositories of food, biodiversity and medicinal plants and their management have set a standard model for the protection of biodiversity, environment and natural resources in CHT (Baten et al., 2010). VCF shows a rich biodiversity compared to government managed reserve forests in CHT (Baten et al., 2010; Adnan \& Dastidar, 2011) although biodiversity is decreasing day by day (Baten et al., 2010). VCF are good examples of effective community-based forest management under certain customary rules and regulations (Baten et al., 2010; Halim \& Roy, 2006) but current trends of forest degradation do not show any sign of hope for tribal communities and the environment. These VCF are under severe threat (Roy \& Halim, 2002; Halim \& Roy, 2006; Tiwari, 2003; Rahman, 2005; Saha, 2010) and in most instances common property regimes seem to have been legislated out of existence (McKean \& Ostrom, 1995). As a result VCF are degrading both 
in quantity (number and size) and quality. Many development projects have been implemented to combat forest loss and land degradation and also to improve the livelihoods of the hill people in CHT involving non-government organizations (NGOs) and other stakeholders (Nath \& Inoue, 2008). But not all initiatives have been successful in attaining their target objectives due to several reasons of which most important are lack of good governance (Nath \& Inoue, 2008b) and also rejection of the approach by the tribal people (Nishat \& Biswas, 2005; Rasul, 2005). Most of these projects were concentrated in swidden commons and reserve forest areas to rehabilitate degraded forests and forest people but no attempt has yet been taken by any government authority to address the issue of VCF in CHT. However, several national and international NGOs are working to improve the management of VCF in $\mathrm{CHT}$ including conservation of biodiversity and improvement of livelihood of the tribal communities (Halim \& Roy, 2006; Saha, 2010; AF, 2010; Nishat \& Biswas, 2005). Acknowledging the enormous social, economic and ecological benefits of the VCF in CHT this paper reviews the political and socioeconomic context of historical establishment and management of $\mathrm{VCF}$, and their role in safeguarding forest and biodiversity resources and at the same time improving the livelihood security of the indigenous communities.

\section{Methodology}

\section{Study Area}

The CHT is located in the south-eastern corner of Bangladesh between $21^{\circ} 25^{\prime} \mathrm{N}$ to $23^{\circ} 45^{\prime} \mathrm{N}$ latitude and $91^{\circ} 45^{\prime} \mathrm{E}$ to $92^{\circ} 50^{\prime} \mathrm{E}$ longitude and is covered with lush green hills, innumerable jharnas (scattered springs) and hundreds of choras (mountain streamlets) (Barkat et al., 2009). The territorial boundary of the region is surrounded by the Arakan (Southern Chin State) of Myanmar and Mizoram state of India in the east, Tripura state of India in the north, Chittagong District in the west and Cox's Bazar district in the south (Figure 1). Geographically it is a part of Hill Tripura and Arakan Yoma branching off from the Himalayan range and continuing to the south through Assam and Hill Tripura of India to Arakan of

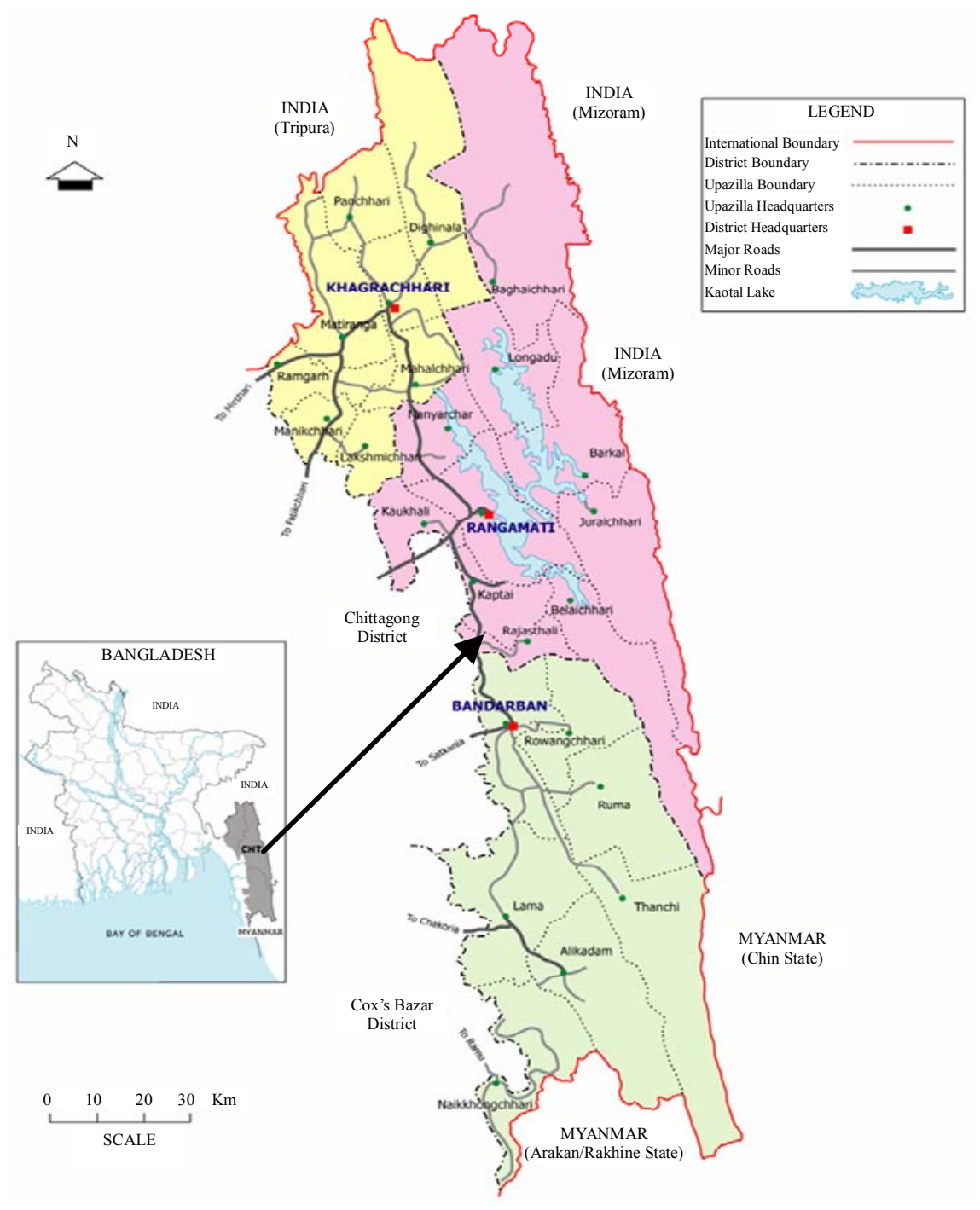

Figure 1.

Map of Chittagong hill tracts (source: Adnan and Dastidar, 2011). 
Myanmar (Roy, 2002; Rasul, 2007). Geographically and culturally this region is distinct from the rest of the country inhibited by a variety of tribes, of which 12 are recorded namely, Chakma, Marma, Tripura, Tanchangya, Mro, Bawm, Kheyang, Pankhu, Chak, Lushai, Khumi and Rakhain (Rasul, 2007; Rasul \& Thapa, 2006; Miah \& Chowdhury, 2004; Chowdhury \& Miah, 2003; van Schendel, Mey, \& Dewan, 2001; Roy, 2000; Khan \& Khisa, 2000; Nasreen \& Togawa, 2002) comprising around $51 \%$ of the total population in CHT (Roy, 2002). However, $98 \%$ of the total ethnic population belongs to Chakma (43.4\%), Marma (25.8\%), Tripura (13.6\%), Tanchangya (9.1\%), Mro (4.5\%), and Bawm (1.5\%) communities (Jamaluddin et al., 2010).

Each community has its own distinct culture and a unique way of life (Khan \& Khisa, 2000). These people live in forest frontiers; depend heavily on forest resources for their sustenance and wellbeing; mostly practicing shifting cultivation as the main source of livelihood. With an area of $13,294 \mathrm{~km}^{2}$, the region covers about one tenth of Bangladesh's land area (Barkat et al., 2009). Administratively the area is divided into three hill districts, namely, Rangamati, Khagrachari and Bandarban and constituting three traditional circles ${ }^{1}$ of Chakma, Mong and Bohmong respectively (Roy, 2000; Chowdhury, 2008; IPP, 2011; Adnan \& Dastidar, 2011; Halim \& Roy, 2006). The topography consists of hills, ravines and cliffs. The hill ranges rise to an average height of about $600 \mathrm{~m}$ (2000 ft.) running in north-east to south-westerly directions (Roy 2000). An estimated $80 \%$ of the CHT is regarded as hilly or mountainous (Roy, 2002; Mohiuddin \& Alam, 2011) with steep slopes that combined with heavy seasonal rainfall $\left(2032-3810 \mathrm{~mm} \cdot \mathrm{yr}^{-1}\right)$ impose limits on arable agriculture, $73 \%$ of the land suitable only for forests, $15 \%$ for horticulture and only $3 \%$ for intensive terraced agriculture in the CHT (Rasul, 2007).

\section{Data and Methods}

The study on historical context was based mainly on seconddary information collected from different journal articles, books, reports and related web information to establish the linkages of VCF development and management. The role of NGOs was also tried to find out in maintaining these VCF. Field visits to a number of VCF in Bandarban hill district, namely, Korang para reserve of Ruma Upazila, Kapru para reserve of Lama Upazila and, Sadar para reserve and Tulachari para reserve of Rowangchari Upazila were also made to cross check the information collected from secondary sources to observe the current status and management pattern of these VCF. The field study was conducted during November 2010 to January 2011 using semi-structured interviews, focus group discussions, key-informant interviews, uncontrolled observations and village walks. Informal discussion with community people and village karbari $^{2}$ were also conducted and an assessment of biodiversity was made by walking through the VCF and indentifying the plant species with a group of experts including community people and in case there was confusion in identifying any species then sample was collected and herbarium sheet was made

\footnotetext{
${ }^{1}$ Circle is an administrative and revenue unit headed by circle chief (raja) who is responsible for the administration of tribal justice and customary laws of the hill people.

${ }^{2}$ Karbari is a village head or elder, always male; an office that is largely hereditary, traditionally nominated by the villagers and formally appointed by the chiefs (Roy, 2004).
}

to identify it later. For animal species the community people were interviewed to name the wildlife they usually observe in the forests and also to name some wildlife they have seen before where the aged people were given preference as they are more knowledgeable.

\section{Results}

Village common forests are natural forests other than the government reserve forests around the households of the indigenous communities and is managed to fulfill their daily demands (Baten et al., 2010; Roy, 2000). VCF refers to any forested area collectively used by village communities that is regarded as common property, irrespective of its legal classification (Roy \& Halim, 2002). According to customary practice, each village identified an area within its territorial and jurisdictional authority reserved solely for use and extraction relating to domestic purposes (Roy, 2000). Historically, indigenous people practice jhum (shifting cultivation) and traditionally keep a patch of forest adjacent to their village, known as a VCF, which is never used for jhum (Islam et al., 2009). They do so mainly for sustained flow of water in the streams but they also get timber, bamboo and other minor forest products from such forests for household use (AF, 2010).

$\mathrm{VCF}$ are commonly owned and managed by the community as a whole responsible for its upkeep and conservation which were later known as the mauza reserves or service forests (Tiwari, 2003; Roy, 2000; Saha, 2010). These forests have also got different names in different tribal communities, like, Jar to the Chakma, Kalittra to the Tripura, Bam or Thoikhuong to the Marma, Reserve to Tanchangya, Bam to Khyiang, Kua Bam to Mru, Kua Reserve to the Bom, Kua Service to the Pankhua, Service to Lusai, Jhumio Pui to Khumi and Thingdhing Aka Ara to the Chaks (Saha, 2010). VCF are mostly small, averageing 20 to 120 hectares in size and consisting of naturally grown or regenerated vegetation (Islam et al., 2009; Halim et al., 2007; Saha, 2010). There is controversy about the total number of VCF but it may be around $700-800$ in CHT (Saha, 2010). VCF play important role in conserving forest resources as well as fulfilling other demands of the forest dependent communities. Some VCF consist predominantly of bamboo brakes, some contain a more heterogeneous stand of flora and fauna, many also contain herbaria for the village concerned, which the local vaidays ${ }^{3}$ use to prepare their traditional medicine, while others are regarded as sacred (Roy \& Halim, 2002). Use and extraction of produce from VCF was need-based with each person taking only what was required, in order not to deplete the natural resources of this forest which existed for the benefit of the entire community (Roy, 2000; Saha, 2010). This system still continues today in some villages and in most cases, VCF are the only remaining natural forests in the surrounding area (Tiwari, 2003; Roy, 2000) and considered as the depository of traditional knowledge (Saha, 2010).

\section{Historical Context of Village Common Forests}

Common property systems have historically governed the management of substantial parts of the world's forest resources that were often subject to some form of effective local control to prevent their overuse. Usually, common property regimes

${ }^{3}$ Vaidays are traditional village shamans or medicine men, also known as ojhas. 
have evolved where the demand on a resource has become too great to tolerate open access use by any longer, so that property rights in the resource have to be created, and where other factors make it impossible or undesirable to allocate the resource to individuals (Arnold, 1998). The use of common land by the tribal people is not new in the region because, since the British colonial period, the indigenous villagers who lost their access to the former common land eventually moved on to the state owned reserve forests. The result was an innovation based upon their traditional resource management patterns to retain forest cover for long-term use. This gave birth to the village common forests of today that are not allowed to be cultivated for jhum or otherwise on the strength of sanctions and religious taboos (Roy \& Halim, 2002), and which are directly managed, protected and used by indigenous village communities (Halim \& Roy, 2006; Rahman, 2005) during the first quarter of $20^{\text {th }}$ century (Baten et al., 2010). For example the Sadar para reserve in Rowangchari Upzila of Bandarban hill district has been established in 1920 (Table 1).

According to the customs of the people of CHT communities, forest and lands were the common property of a specific clan or village community (Chakma et al., undated). The concept of land rights (including forest lands) and individual ownership was governed by the prevailing customs of the respective communities. These were all oral traditions rather than written laws (Adnan \& Dastidar, 2011; Lasimbang, 2006) institutionalized in the form of social codes or norms mutually upheld by the community. Usually, common rights refer to the generic rights of the hill people through customs and practices that include entitlement to jhum, hunting and gathering, livestock grazing, village common forests, and various other land and forest-based extraction activities (Adnan \& Dastidar, 2011; Chakma et al., undated). Circle chiefs, mauza ${ }^{4}$ headmen and karbaris regulate these rights and distribute both jhum and plough lands among the hill peoples for cultivation. Some of these common rights are partially acknowledged and regulated but very few are clearly defined. The right to occupy homestead land in rural areas (Rule 50, CHT Regulation I of 1900) without formal settlement and the right to use timber, bamboo, and other minor forest produce for bona fide domestic purposes (Rule 41A, CHT Regulation I of 1900; Forest Act 1927) are reserved exclusively for indigenous people (Roy, 2004). The individual rights give individuals entitlement over clearly demarcated land whether as freehold (rights with perpetuity) or leased (rights for a specific period) that includes private forests, commercial plots and plough lands. The significant aspect of British colonial land policy in CHT was that land could neither be sold nor purchased, and was reserved for the hill people or the government (Chowdhury, 2008). In contrary, Pakistan period can be characterized by intensification of resource use for industrial purpose and Bangladesh period by large scale migration of lowland people to CHT that significantly affected the access and use of forests resources (Rasul \& Thapa, 2005) creating brutal conflicts between tribal communities and settlers, and more than two decades of insurgency which is theoretically ended up by signing a peace accord in 1997 between the Government of Bangladesh and Jana Sanghati Samiti (JSS), an organization representing indigenous people of the CHT.

\footnotetext{
${ }^{4}$ Mauza is the smallest administrative unit for revenue collection in the CHT containing several villages or hamlets with an average size of 10 miles square and head of the mauza is responsible for the administration of revenue, land, and tribal justice (Roy, 2004).
}

Table 1.

Description of village common forests.

\begin{tabular}{|c|c|c|c|c|c|}
\hline \multicolumn{2}{|c|}{ Location } & \multirow{2}{*}{ Ethnicity } & \multirow{2}{*}{$\begin{array}{c}\text { No. of } \\
\text { households }\end{array}$} & \multirow{2}{*}{$\begin{array}{c}\text { Area } \\
\text { (ha) }\end{array}$} & \multirow{2}{*}{$\begin{array}{c}\text { Year of } \\
\text { establishmen }\end{array}$} \\
\hline Upazila & Village & & & & \\
\hline Ruma & Korang para & Mro & 27 & 40 & Unknown \\
\hline Lama & Kapru para & Mro & 38 & 80 & Unknown \\
\hline Rowangchari & Sadar para & Marma & 330 & 100 & 1920 \\
\hline \multirow[t]{2}{*}{ Rowangchari } & $\begin{array}{c}\text { Tulachari } \\
\text { para }\end{array}$ & Marma & 35 & 8 & Unknown \\
\hline & Average & & 107.5 & 57 & - \\
\hline
\end{tabular}

Common property regime can emerge as a way to secure control over a territory or a resource, to exclude outsiders or to regulate the individual use by members of the community (Arnold, 1998). As such, the birth of community-managed VCF in the $\mathrm{CHT}$ is a direct result of resource constraints caused by deforestation and the prevention of entry into and use the resources of the newly acquired reserved forests (Halim \& Roy, 2006; Baten, et al., 2010). According to Nayak (2002) the negative impacts of forest degradation on the local agriculture and animal husbandry practices had completely traumatized the forest based livelihood of many for which people started travelling to far off forest areas for need fulfillment resulting in conflicts with other communities and harassment by the government forest department. On the other hand ecological effects of forest degradation i.e. loss of soil fertility, erratic rainfall and drying-up of streams, have also played a significant role in inducing forest protection by local communities. In such circumstances many communities gradually turned to their adjacent degraded forests and initiated protection measures perhaps as a last resort to restore back the forests and local livelihoods. Gradually, such local efforts turned the negative impacts of forest degradation into initiating factors for community-based forest management (CFM) in India that resulted from a desire to save forest patches for the posterity and also quite strikingly from an urge to assert the villagers control over the forest patch otherwise open to all (Panigrahi, 2006). Local communities joined hands in bringing forestlands under their de facto (customary ownership without any legal right) control. Once protection by a few started, communities were quick to learn from each other and soon large tracts of forestland came under community protection and management (Nayak, 2002). CFM initiatives has brought recognition and pride to many villages and has been a strong driving force motivating other villages in the neighborhood to undertake protection and regeneration of degraded forest patches and evolved as a socio-cultural movement that is not restricted to forest protection only. Experiences from India suggest that in certain areas, communities engaged in forest protection christened themselves as "forest caste" to strengthen the relationship existing with forest, in many cases also helped the local communities in establishing new relationships through marriage, some communities prohibited marriage of their children in non-protecting villages, and an exciting practice is followed in some CFM villages where every newly wedded couple during marriage goes for planting trees to mark the beginning of their conjugal life (Panigrahi, 2006).

Reviews of related literatures suggest that the development of VCF in the CHT by the tribal communities started due to 
some socio-political and administrative reasons. First, the nationalization of forests and declaring one fourth of the CHT land as reserve forests by the British colonial government denying the customary rights of the indigenous people have restricted most of the open access resources to the tribal communities and eventually opening the forest for commercial exploittation where the government encouraged the extraction of forest products and invited traders to extract timber from forests (Rasul, 2005; Rasul \& Thapa, 2005). Before the nationalization, the community had the responsibility to conserve forest resources within their jurisdiction where there were community sanctions and respected rules and norms prevented forest encroachment by outsiders (Rasul \& Karki, 2006; Thapa \& Rasul, 2006). Second, entrusting the management of forests to centralized government departments that created conflicts regarding resource access and use among government authorities and tribal communities. Local forests were marked, reserved and subsequently plundered for commercial purposes (Nayak, 2002). The Forest Department, the only authority to manage state forests, also failed to assert effective control over forest resources owing to the remoteness of the area, difficult terrain and inadequate and inefficient human and logistical resources. Third, weakening of the traditional institutions (Rasul \& Karki, 2006; Rasul, 2005, 2007; Rasul \& Thapa, 2005; Chowdhury, 2008) through appointment of mauza headmen by the Deputy Commissioner based on the nomination from concerned circle chiefs replacing the traditional democratic local governance system of selecting leaders by community people themselves. As the headmen were appointed by the DC, they were not accountable to the local people who they represented. Instead, they were accountable to the circle chiefs and the DC. This change weakened the traditional institutions that controlled the use of forest resources by outsiders, giving outsiders open access to forest resources and affecting the management of CHT forest resources. As a result, the abolition of the customary resource management system led to the indiscriminate exploitation of forest resources (Thapa \& Rasul, 2006). Fourth, the widespread forest degradation due to population pressure, commercial forest exploitation by both state sponsored and illegal logging, intensified shifting cultivation through shortening of fallow periods (Nath \& Inoue, 2008; Nath, Inoue, \& Hla Myant, 2005b; Roy, 2000; Banerjee, 2000) as a result of restriction to access reserve forests, policies declaring reserve forests (Banerjee, 2000) that displaced most of the indigenous peoples and thereby converting common property resources to open access resources, introduction of sedentary agriculture, monoculture teak plantations by clearing forest patches, decreased access to land due to Kaptai Dam and resultant internal displacement, development of road networks and market facilities that encouraged more resource destruction, have increased competition among and within the communities so that the indigenous peoples suffered shortage of forest resources that in turn made them to go far off the forests requiring more time and sometimes creating conflicts between communities and government authorities (Nayak, 2002). Fifth, the need to secure continued water supply for the community in addition to forest resources (Baten et al., 2010; AF, 2010) as they realized from experience that forests with trees especially the indigenous ones are the source of water in the streams and creeks. Finally, the acknowledgement of mauza reserves or community based forests in the CHT Regulation 1900 and Indian Forest Act 1927 have also paved the way to start and manage village common forests by the communities. In response to these situations indigenous communities have considered VCF as security of rights and daily necessities. However it is the widespread deforestation both at state and individual levels that paved the way for the development of VCF in CHT. Tenure insecurity has acted as incentive to manage forest for long term use and in some cases as disincentive to overuse of resources. Again remoteness of the villages from market places may also be considered as a factor for development of VCF or collaborative management to secure daily necessities from the forests.

\section{Socio-Political and Administrative Context}

The topic of natural resource management in the CHT is complex, multidimensional, and incredibly political (Tiwari, 2003). The tribal communities have inhabited this area for hundreds of years without degrading physical environment and depleting natural resources (Uddin, 2008). The CHT of Bangladesh underwent essentially the same socio-political and historical processes as many other countries in the region and had very similar experiences in forest management (Rasul, 2007). Bangladesh evolved as a sovereign independent nation through a long process of political and administrative changes extending over a period of several centuries. As part of greater India, Bangladesh was colonized by Britain from 1760 until 1947. Following independence, it became a part of Pakistan and remained so until its emergence as an independent nation in 1971. Policies and laws adopted during different politico-administrative periods have had a direct bearing on forest commons in the CHT. The CHT administrative system includes both formal government institutions and the semi-formalized, traditional offices of the three circle chiefs (Roy, 2000; Chowdhury, 2008; IPP, 2011; Halim \& Roy, 2006; Roy, 2004), 380 mauza headmen (Roy, 2004; Halim \& Roy, 2006), and karbari in each community village or para. The CHT legal system incorporates both codified and customary laws. Therefore, the rights over forests and other land may not always be clearly defined as a result of the existence of overlapping rights to the same parcel of land. There are also conflicting provisions in the various laws, including the British promulgated CHT Regulations of 1900 on the one hand and the Hill District (Local Government) Council Acts of 1989 and the CHT Regional Council Act of 1998 on the other (Roy, 2002). The existence of mauza reserves has been acknowledged in the CHT Regulation of 1900 (Rule 41A), the main legal instrument for the administration of the region and the primary responsibility to protect these forests is vested upon the mauza headmen (Halim et al., 2007; Halim \& Roy, 2006; Roy, 2000). A number of ancillary executive orders of the district administrations were passed during the British period and the Pakistan period, but have otherwise suffered from policy neglect since then (Halim et al., 2007; Halim \& Roy, 2006). Although the law does recognize the existence of $\mathrm{VCF}$, neither the law concerned, nor subsidiary or ancillary rules, regulations or guidelines expressly provide for any system of titling or registration or other safeguards against privatezation, alienation or permanent and detrimental change in resource use patterns (Halim \& Roy, 2006). This responsibility would appear to rest upon the mauza headman as no land grants are generally made without his advice in the CHT, although there are some notable exceptions (Halim et al., 2007).

Various policies and programs have been implemented in the Chittagong Hill Tracts from the time of British colonial period 
to the present national administration. The forest policies implemented in CHT in the name of nationalization of forests by declaring one-fourth of the land area as reserved forests highlights a systematic pattern of violations of the traditional land and resources rights of the indigenous people that trusted to strengthen overall national development, with little regard for their impact on the indigenous people and traditional way of life (Roy, 2000; Ali \& Tsuchiya, 2002). These policies had a major impact on the basic social, cultural and economic rights of the indigenous people. The procedure of creating reserve forests includes a concomitant loss of land and related resource rights for the hill people, where no consideration was given to their needs or to their ancestral rights to the forests and their produce, many of which were recognized by the CHT regulation of 1900, without paying any compensation; considerable decrease of lands remaining open and accessible to the indigenous people for their livings; curtailment of subsistence activeties due to prohibited activities in the reserved forests and difficulty in seeking alternative avenues for income generation due to restriction on hunting and gathering forest products leading the indigenous people towards no alternative but to enter the reserved forests for use and extraction to meet their daily requirements and in some cases for commercial purposes; hundreds of indigenous people have been, and still are, internally displaced and many indigenous people have become homeless in addition to having no resource base for their economic activities; and finally the most worst impact to be the criminalizetion of the principal economic activities of indigenous people like, trapping or hunting, gathering forest products, and jhuming (Roy, 2000). The problem has become more acute after the construction of the Kaptai Dam in 1960 that displaced some 100,000 inhabitants; land dispossession at the hands of government-sponsored Bengali settlers; acquisition of land for new "reserved forests"; allotment of customarily-owned lands to non-resident entrepreneurs for rubber and other commercial plantations; and "privatization" of former commonly-held areas (Roy, Hossain, \& Guhathakurta, 2007). To be honest the tribal people have experienced to be alienated from their land through centuries, and are still struggling to get recognition of their right to access and use their ancestral land (Mjanger, 2008). The combined effect of all these policies and administrative systems have initiated the forest resource management at the community level based on traditional knowledge and innovation to secure their daily necessities from the forests and as a result village common forests have been established around the homesteads or near the villages of the indigenous communities in the CHT.

\section{Management of Village Common Forests}

Indigenous communities worldwide are generally very knowledgeable about the natural resources in their surroundings on which they depend intimately (Khisa, 1998) and have demonstrated their skills in forest management in the CHT (Roy, 2002). Indigenous knowledge, innovations and practices on natural resource management are little understood by outsiders yet are highly complex systems, closely interlinked with other indigenous systems that incorporate a keen awareness of the environment, an appreciation for conservation and continuity, encourage sustainable innovation, and place the long-term well being of the community as the focus of all activities (Lasimbang, 2006). The indigenous communities are managing VCF around their homesteads with the objective to maintain tree cover and protect the environment in the face of rapid deforestation, to maintain a diversity of plants and animals (including herbs and plants used in herbal medicine), to sustain a supply of wood and bamboo required for house construction and fuel consumption, to reduce the pressure on government managed reserved forest for forest products, and finally to ensure the source of water by keeping annual and perennial springs and small rivers into sustained flow and secure sustainable access to livelihood resources (Baten et al., 2010; Islam et al., 2009; AF, 2010). Women are the primary users of these forests, as the forests are used primarily to meet household needs (Tiwari, 2003).

The VCF are managed, protected and utilized by indigenous village communities under the leadership of the mauza headman or village karbaris or by educational or religious institutions, or a committee formed by leaders from one or more villages (Halim et al., 2007; Islam et al., 2009; Tiwari, 2003; Roy, 2000; AF, 2010). Use and extraction was need-based with each person taking only what was required, in order not to deplete the natural resources of this forest which existed for the benefit of the entire community (Tiwari, 2003; Roy, 2000; Saha, 2010; Islam et al., 2009). There are no written rules for VCF management but there are traditional rules which differ with different ethnic communities and also with local condition (Baten et al., 2010; Tiwari, 2003, Islam et al., 2009). However, some rules are common for all the VCF that are strictly followed with the provision of penalties or sometimes exclusion from the clan in case of rules violation such as, Jhuming and hunting are strictly prohibited, all sorts of fireworks and unpermitted access are restricted in the VCF area, a penalty of Tk. 50 for each bamboo has to be paid if anybody cuts bamboo without permission, immature bamboo extraction is restricted, harvesting of bamboo is generally done every 2 to 3 years, new plantation should be done by the members every year, the executive committee will approve the requirement of forest resources in general meeting before starting extraction, commercial selling is forbidden unless the committee decides to spend the money out of the selling of forest products in community development (developing educational or religious institutions, roads, etc.), committee can also permit outside villagers to collect forest resources in case of emergencies (Baten et al., 2010; Tiwari, 2003; Roy, 2000; Saha, 2010). Sometimes mature trees and bamboos are sold to create a fund to be used in disaster. Limited collection of resources at limited time period is also allowed as custom and there is an option to harvest trees or bamboos from the VCF with the prior permission from the management committee for building or repairing houses, funeral of deceased or any other need. So the management of VCF in the $\mathrm{CHT}$ is concentrated on the regulation of access to and use of the resources, keeping the forests undisturbed for long time period and protecting the forests from illegal harvesting by the concerned community members including patrolling the forests on rotation. Village Common Forests thus managed by indigenous communities have set a standard model for the protection of biodiversity, environment and natural resources in CHT (Baten et al., 2010) and as such the indigenous people have proved themselves to be efficient managers and custodians of forests in CHT and elsewhere (Halima \& Roy, 2006; Nayak, 2000). In fact, the indigenous peoples of CHT have a rich tradition of maintaining and protecting their naturally grown or regenerated village forest commons that might be a cause for 
shame for many forest officials with their formal knowledge on forestry and biodiversity (Roy, 2004) as there is growing recognition that governments and public forest management agencies often have not been good stewards of public forests (White \& Martin, 2002).

\section{Current State of VCF}

The indigenous communities are living in the CHT for hundreds of years without degrading physical environment and depleting natural resources. The way they exploited and managed their environment and natural resources are quite sustainable (Uddin, 2008) based on local traditional knowledge and custom. According to Panigrahi (2006), the success of community based institutional arrangement (the management committee formed by the community, and the community regulations and sanctions) lay on the inherent processes, which are democratic, flexible and have emerged responding to local situations and context. Local management institutions play a positive role in the area, but their impact appears insufficient to safeguard forests and commons from continued degradation (Heltberg, 2001). Over the last 2 - 3 decades, the military forces, traders, government officials, and settlers have devastated the CHT rain forests through indiscriminate illegal logging, excessive timber, fire-wood and bamboo extraction for commercial and industrial purposes and displaced most of the tribal people both internally and externally demolishing their ancestral homeland and the remaining rain forests including the village common forests in search of rich natural resources using "national development and security" as an excuse (Uddin, 2008). At the same time promotion of market oriented horticulture and tree plantations also led to the conversion of many VCF into orchards and plantations (Roy \& Halim, 2002). Indigenous communities face continuous threat of losing the VCF adjoining their homesteads because they do not have formal title (or common ownership) over them that again has been deepened by recent attempts of the Forest Department to acquire VCF for afforestation projects by claiming that these are mere "jungles" situated on state lands (Adnan \& Dastidar, 2011). Another threat to the VCF arises from privatization by elite tribal people, including concerned mauza headmen and village karbaris in some instances who are concerned to convert these common forests into homesteads, orchards and other forms of private property, often with formal settlements and registered titles. This has been motivated from enhancing subsistence production to maximizing profit through market based commercial production that has been heightened by the lack of awareness of land rights among their fellows as well as the erosion of traditional egalitarian and redistributive norms among the indigenous communities of the CHT (Adnan \& Dastidar, 2011).

The conflicts between the tribal people and the settlers in the CHT has long been a cause of violation of human rights of the inhabitants, obstruction in the path of sustainable development, as well as ecosystem destruction, loss of biodiversity and natural resource degradation (Rahman, 2005). During the counterinsurgency, the security forces often evicted tribal people from their lands to set up their own camps and installations without following due state acquisition procedures and also acted similarly to seize hilly lands for housing Bengali settlers brought in through the transmigration programme, disregarding the preexisting land rights of the indigenous people (Adnan \& Dastidar, 2011). In these situations the VCF in the CHT are gradu- ally degrading in quantity and quality which were managed as collective action by the communities not for large timber revenues but for ensuring day-to-day requirements that does not necessarily depend on land tenure, at least in the short run (Talwar \& Ghate, 2003). But in the changed circumstances of the present day, common village forests are under threat primarily due to tenure insecurity resulting from population pressure and consequent growth of village settlements, scarcity of lands, spread of sedentary agriculture, horticulture and tree plantations, and frequent in-migration and out-migration, lack of institutional support and other socio-political reasons (Roy \& Halim, 2002; Tiwari, 2003; Rahman, 2005; Saha, 2010; Halim \& Roy, 2006) as insecure property rights are one of the main causes of deforestation in contrast to secure tenure that result in improved management and conservation of forests (Sunderlin, Hatcher, \& Liddle, 2008). We observed that, the VCF of Kapru para, situated down slope of the right side of BandarbanThanchi road and opposite from Nilgiri Parjaton Complex, is very rich in biodiversity with naturally grown vegetation and wildlife species having enormous potential for tourism and nature walk combined with rich cultural tradition of the Mro community. Community people were found very conservative to let outsiders know about their culture or natural resource management as they have fear of alienation from their land in the name of development project by the government or private initiatives. But if the government secures their rights on the forests then community people can easily utilize the potential of this forest for tourism and can earn alternative income that will surely reduce their dependency on forest resources and conserve the biodiversity of the region.

The policy neglect since the 1960 s has also led to further diminishment of the number and extent of VCF (Halim \& Roy, 2006). According to Islam et al. (2009) communities which are not permanently settled tend to overexploit the VCF making these community forests unsustainable. Tenure security also has a strong role in the structure of incentives that motivate protecttion or destruction of forests as it is often the foundation for the social identity, personal security, and cultural survival of indigenous peoples and ethnic minorities (Sunderlin, Hatcher, \& Liddle, 2008). Halim et al. (undated) found that reserve forests that are located in remote areas are also getting denuded quickly with little tendency to plant trees due to insecurity of tenure where the indigenous communities have become de facto managers of the forests in absence of control by the Forest Department and managed the forests sustainably for long. Tenure insecurity acted as incentive to manage VCF in order to establish right over the resources and restrict outsiders' access and also secure daily necessity from the forests in the face of increased competition among communities due to nationalization of forests, policy recognition, population pressure and shortage of forest resources. Again, tenure insecurity also acted as disincentive to deplete and degrade VCF due to weakening of the traditional system, government sponsored settlement programs, development of road networks and market facilities, long insurgency period as a result of conflicts between military and indigenous people, privatization and commercial plantations.

Field visits to different VCF in Bandarban hill district and discussion with the community peoples and village leaders show that the VCF are necessarily small in size (on average 57 ha) and on average a total of 108 families are dependent on these community managed village forests (Table 1). These forests are managed by the community people usually by a 
committee formed from the community people involving mauza headmen and/or village karbari. Village common forests in Kafru para and Korang para are especially maintained as a source of safe drinking water for the community people. They do not cut trees or bamboos from the reserve. But if some one cut or extract any resource without prior permission of such committee or steal any resource from the reserve then he is fined for his action. In Sadar para reserve the management committee selects 30 people each month from the community to go into the reserve and clearing the jungle or weeds to give new tree or bamboo regeneration better chance to grow freely. Every week they go inside the reserve in small group on rotational basis and patrol the reserve to protect it from any sort of theft or stealing or illegal cutting of trees or bamboos (as in the case of Sadar para reserve which is situated at $4-5 \mathrm{~km}$ distant from their village). According to the community people in $\mathrm{Sa}$ dar para reserve they will decide after 20 years whether to cut trees or bamboos from the reserve. However poor people will be allowed to extract any resource from the reserve to meet their emergency needs if they seek permission from the management committee. The community people usually live on jhum, sedentary agriculture (as in the case of Tulachari para), day labor or small business and also collect fuel wood and banana for own consumption or sale from the nearby forest areas of their reserves. They, especially the women, also collect different types of herbs, vines or leaves from the VCF, nearby forests or jhum fields for cooking purposes or to use as medicine. Both male and female members of the family work in the jhum field or as paid labor. However there is marked differences in wage rates. Women usually get less wage rate (US\$ 1.50 per day) compared to their male counterpart (US\$ 3.00 per day) for the same work load as mentioned by the community people which make the women as disadvantaged group of the community.

Forest survey shows that these VCF still harbor huge plant diversity including some rare plants and animals as these are maintained as para reserves for long and biodiversity are occurring naturally. The VCF can easily be identified with their thick canopy coverage consisting of naturally grown bigger trees, bamboos, and other plant species in or around the tribal villages. A total of 163 plant species from 60 families has been recorded during the field visits (Table 2) which is more or less similar to the findings of Baten et al. (2010) who found 173 floral species from the VCF in CHT. Important plant species found are Dipterocarpus turbinatus (Garjan), Swintonia floribunda (Civit), Artocarpus chaplasha (Chapalish), Ficus lepidosa (Dumur), Ficus semicordata (Jaganna gula), Albizia spp. (Koroi), Podocarpus nerifolia (Banspata), Michelia champaca (Champa), Cedrela toona (Toon), Duabanga grandiflora (Bandarhola), Trewia polycarpa (Pitali), Anogeissus acuminate (Fuljhumuri), Mesua nagassarium (Nagesswar), Stereospermum spp. (Dharmara), Hydnocarpus kurzii (Chal mugra), Castanopsis tribuloides (Batna), Aphanamixis polystachya (Pitraj), Lagerstroemia speciosa (Jarul), Terminalia belerica (Bohera), Terminalia chebula (Haritaki), Phyllanthus emblica (Amloki), Mangifera sylvatica (Uriam), Syzygium cumini (Kalo Jam), Melocanna baccifera (Muli bans), Bambusa tulda (Mitinga bans), Bambusa teres (Pharua bans), Dendrocalamus longispathus (Ora bans), Calamus latifolius (Kerak bet), Calamus tenuis (Jali bet) and Calamus guruba (sundi bet), Thysanolacana maxima (Fuljaru), Imperata arundinaceae (Shan grass), Pteris cretica (Dheki shak), Paederia foetida (Gandha vaduli), etc.

The forests are also rich in wildlife biodiversity including Macaca mulatta (Rhesus Macaque), Sus scrofa (Wild Pig), Muntiacus muntiak (Barking deer), Panthera pardus (Indian Leopard), Felis chaus (Jungle cat), Hystrix indica (Porcupine), Ophiophagus hannah (King Cobra), Python reticulata (Python), Caloted versicolor (Monitor Lizard), Varanus begalansis (Bengal Monitor Lizard), Suncus murinus (Grey Musk Shrew), Helogale parvula (Common Mongoose), Viverra zibetha (Civet), Lutra lutra (Common otter), Vulpes bengalensis (Bengal fox), Vulpes vulpes (Red fox) Pteropus giganteus (Indian flying fox), Gallus gallus (Red jungle fowl), Elanus caeruleus (Blackwinged Kite), Lophura leucomelanos (Mathura), Bubo spp. (Owl), Lonchura spp. (Munia), and other common birds, mammals and reptiles. According to the community people, even 40 years ago, the whole area was one of the deepest forests famous for diversified flora and wildlife species. The area was once home of Elephas maximus (Elephant), Panthera spp. (Tiger), Rhinoceros unicornis (Great one-horned rhinoceros), Rhinoceros sondiacus (Javan rhinoceros), Didermocerus sumatrensis (Asiatic two-horned rhinoceros), Ursus thibetanus (Asian black bear), Boselaphus tragocamelus (Nilgai), Bubalus bubalis (Wild buffalo), Bos frontalis (Gayal), Bos gaurus (Gaur), Bos banteng (Banteng), Cervus unicolor (Sambhar), Axis porcinus (Hog deer), Canis lupus (Marbled cat), Rhodonessa caryophyllacea (Pink headed duck), Pavo cristatus (Common peafowl), Polyplectron bicalcaratum (Peacock-pheasant), Accipiter spp. (Hawk), Aquila spp. (Eagle), etc.

\section{Discussion}

We found that VCF still are the source of fuel wood, herbs, roots, bamboo shoots, wild fruits, vines or leaves for cooking or medicinal use necessary to sustain the lives of the indigenous communities in the CHT. VCF are also very rich in biodiversity harboring rare plant and animal species which are not usually found in the reserve forests (administered by the Forest Department) and the un-classed state forests (also known as swidden commons, administered by the Deputy Commissioner) due to continued deforestation and land degradation. The indigenous communities are the important stakes of this rich biocultural system that have survived many centuries as model system of natural resource management and socio-cultural harmony with nature. This was possible by their traditional institutions governing the natural resources as common property system based on social, cultural and religious beliefs. Traditionally the indigenous communities are smaller in size (generally less than 100 families) having strong social, cultural or religious kinship and are organized by the village elders or leaders, used to be selected democratically from the community, who hold a strong position upon the community members with their knowledge, experiences, leadership quality and indigenous customs to guide and support their fellow members in their socioeconomic, cultural and religious activities. Ciriacy-Wantrup \& Bishop (1975) also mentioned that institutions based on the concept of common property have played socially beneficial roles in natural resources management from economic prehistory up to the present. So the role of institutions is very important for the sustenance of these VCF in the CHT. But unfortunately these traditional institutions have been weakened without giving much consideration on traditional resource management systems or their socio-cultural life enforcing several polices aimed 
Table 2.

List of plant species found in the village common forests of Bandarban hill district with their family name, scientific name, nature and status $(\mathrm{VC}=$ Very common (observed everywhere in greater numbers); $\mathrm{CO}=$ Common (observed everywhere); $\mathrm{VU}=$ Vulnerable (observed only in 2 - 3 occasions); EN = Endangered (observed only once or confirmed by the community people to be present in the forest); $P L=P l a n t e d)$.

\begin{tabular}{|c|c|c|c|c|c|}
\hline Sl. No. & Family & No. of Species & Scientific Name & Nature & Status \\
\hline \multirow[t]{3}{*}{1} & Achariaceae & 1 & Hydnocarpus kurzii & Tree & EN \\
\hline & & & Anacardium occidentale & Tree & $\mathrm{CO}$ \\
\hline & & & Mangifera indica & Tree & PL \\
\hline \multirow[t]{3}{*}{2} & Anacardiaceae & 5 & Mangifera sylvatica & Tree & VU \\
\hline & & & Spondias indica & Tree & EN \\
\hline & & & Swintonia floribunda & Tree & EN \\
\hline \multirow[t]{3}{*}{3} & Annonaceae & 1 & Artabotrys uncinatus & Climber & $\mathrm{CO}$ \\
\hline & & & Alstonia macrophylla & Tree & EN \\
\hline & & & Holarrhena floribunda & Shrub & $\mathrm{CO}$ \\
\hline \multirow[t]{4}{*}{4} & Apocynaceae & 5 & Odontodenia speciosa & Climber & VU \\
\hline & & & Roupelia grata & Climber & EN \\
\hline & & & Wrightia tomentosa & Shrub & $\mathrm{VC}$ \\
\hline & & & Aglaonema crispum & Herb & VU \\
\hline \multirow[t]{2}{*}{5} & Araceae & 3 & Anthurium pedato-radiatum & Herb & $\mathrm{VU}$ \\
\hline & & & Colocasia nymphaefolia & Herb & $\mathrm{CO}$ \\
\hline \multirow{8}{*}{6} & & & Aiphanes caryotaefolia & Shrub & $\mathrm{VU}$ \\
\hline & & & Areca catechu & Tree & $\mathrm{VU}$ \\
\hline & & & Attalea cohune & Shrub & $\mathrm{VU}$ \\
\hline & $\Delta$ rococon & 8 & Calamus guruba & Rattan & $\mathrm{CO}$ \\
\hline & Aiventede & ${ }^{0}$ & Calamus latifolius & Rattan & $\mathrm{VU}$ \\
\hline & & & Calamus tenuis & Rattan & VU \\
\hline & & & Licuala grandis & Shrub & VU \\
\hline & & & Livistonia rotundifolia & Tree & $\mathrm{CO}$ \\
\hline 7 & Aristolochiaceae & 1 & Aristolochia grandiflora & Climber & $\mathrm{CO}$ \\
\hline \multirow{6}{*}{8} & & & Ageratum conyzoides & Shrub & $\mathrm{CO}$ \\
\hline & & & Artemisia absinthium & Herb & $\mathrm{CO}$ \\
\hline & $\Delta$ stor & 6 & Eupatorium odoratum & Shrub & $\mathrm{VC}$ \\
\hline & Asteracede & 0 & Eupatorium odoratum & Climber & $\mathrm{VC}$ \\
\hline & & & Eupatorium ayapana & Herb & $\mathrm{CO}$ \\
\hline & & & Mikania cordata & Shrub & VU \\
\hline 9 & Begoniaceae & 1 & Dolichandrone spathacea & Tree & VU \\
\hline \multirow{4}{*}{10} & & & Heterophragma adenophyllum & Tree & $\mathrm{CO}$ \\
\hline & & & Oroxylum indicum & Tree & $\mathrm{CO}$ \\
\hline & Bignoniaceae & 4 & Stereospermum chelonioides & Tree & VU \\
\hline & & & Stereospermum personatum & Tree & VU \\
\hline
\end{tabular}


Continue

\begin{tabular}{|c|c|c|c|c|c|}
\hline 11 & Bixaceae & 1 & Bixa orellana & Tree & $\mathrm{CO}$ \\
\hline 12 & Boraginaceae & 1 & Cordia туха & Tree & VU \\
\hline 13 & Bromeliaceae & 1 & Ananus comosus & Herb & PL \\
\hline \multirow{2}{*}{14} & \multirow{2}{*}{ Burseraceae } & \multirow{2}{*}{2} & Garuga pinnata & Tree & VU \\
\hline & & & Protium serratum & Tree & VU \\
\hline 15 & Calophyllaceae & 1 & Mesua nagassarium & Tree & EN \\
\hline 16 & Cannabaceae & 1 & Trema orientalis & Tree & EN \\
\hline \multirow{2}{*}{17} & \multirow{2}{*}{ Clusiaceae } & \multirow{2}{*}{2} & Garcinia cowa & Tree & $\mathrm{VU}$ \\
\hline & & & Garcinia paniculata & Tree & VU \\
\hline \multirow{4}{*}{18} & \multirow{4}{*}{ Combretaceae } & \multirow{4}{*}{4} & Anogeissus acuminata & Tree & $\mathrm{CO}$ \\
\hline & & & Calycopteris floribunda & Climber & $\mathrm{VC}$ \\
\hline & & & Terminalia chebula & Tree & VU \\
\hline & & & Terminalia belerica & Tree & $\mathrm{VU}$ \\
\hline \multirow{2}{*}{19} & \multirow{2}{*}{ Convolvulaceae } & \multirow{2}{*}{2} & Argyreia nervosa & Climber & $\mathrm{CO}$ \\
\hline & & & Argyreia populifolia & Climber & $\mathrm{CO}$ \\
\hline 20 & Costaceae & 1 & Costus speciosus & Herb & $\mathrm{VU}$ \\
\hline 21 & Cyclanthaceae & 1 & Cyclanthus bipartitus & Herb & EN \\
\hline \multirow{2}{*}{22} & \multirow{2}{*}{ Dilleniaceae } & \multirow{2}{*}{2} & Dillenia indica & Tree & $\mathrm{VU}$ \\
\hline & & & Tetracera sarmentosa & Climber & $\mathrm{CO}$ \\
\hline 23 & Dioscoreaceae & 1 & Dioscorea bulbifera & Herb & $\mathrm{VC}$ \\
\hline \multirow{2}{*}{24} & \multirow{2}{*}{ Diptercarpaceae } & \multirow{2}{*}{2} & Anisoptera scaphula & Tree & EN \\
\hline & & & Dipterocarpus turbinatus & Tree & EN \\
\hline \multirow{2}{*}{25} & \multirow{2}{*}{ Dryopteridaceae } & \multirow{2}{*}{2} & Drynaria roxburghii & Fern & $\mathrm{CO}$ \\
\hline & & & Polystichum setosum & Fern & $\mathrm{CO}$ \\
\hline \multirow{2}{*}{26} & \multirow{2}{*}{ Ebenaceae } & \multirow{2}{*}{2} & Diospyros peregrina & Tree & $\mathrm{VU}$ \\
\hline & & & Diospyros ramiflora & Tree & $\mathrm{VU}$ \\
\hline 27 & Elaeocarpaceae & 1 & Elaeocarpus robusta & Tree & $\mathrm{CO}$ \\
\hline \multirow{8}{*}{28} & \multirow{8}{*}{ Euphorbiaceae } & \multirow{8}{*}{8} & Bridelia scandens & Shrub & $\mathrm{VC}$ \\
\hline & & & Croton oblongifolius & Tree & $\mathrm{VU}$ \\
\hline & & & Drypetes roxburghii & Tree & $\mathrm{CO}$ \\
\hline & & & Euphorbia leucocephala & Climber & $\mathrm{CO}$ \\
\hline & & & Mallotus rependus & Shrub & $\mathrm{VC}$ \\
\hline & & & Mallotus roxburghianus & Shrub & EN \\
\hline & & & Phyllanthus reticulatus & Shrub & $\mathrm{VC}$ \\
\hline & & & Trewia polycarpa & Tree & VU \\
\hline
\end{tabular}


29

Fabaceae

30

31 Hypoxidaceae

32

Lamiaceae

36

Malvaceae
Acacia nilotica

Albizia falcataria

Albizia procera

Bauhinia vahlii

Brownea coccinea

Caesalpinia insigna

Cajanus cajan

Cassia auriculata

Derris robusta

Erythrina variegata

Indigofera tasmania

Indigofera tinctoria

Meliotus alba

Mimosa pudica

Mucuna monosperma

Mucuna utilis

Tamarindus indica

Uraria logopoides

Castanopsis tribuloides

Curculigo capitulata

Callicarpa arborea

Callicarpa macrophylla

Clerodendrum squamatum

Clerodendrum viscosum

9

Gmelina arborea

Gmelina hystrix

Hyptis suaveolens

Tectona grandis

Vitex glabrata

Leea macrophylla

Lagerstroemia speciosa

Michelia champaca

Abroma augusta

Bombax ceiba

Ceiba pentandra

Gossypium barbadense

Hibiscus furcatus

Microcos paniculata

Pterospermum acerifolium

Pterospermum suberifolium

Sterculia villosa

Urena lobata

Tree EN

Tree VU

Tree $\quad \mathrm{CO}$

Climber VC

Tree $\mathrm{CO}$

Climber VC

Shrub PL

Shrub VU

Tree $\mathrm{CO}$

Tree $\mathrm{CO}$

Shrub CO

Shrub VU

Herb CO

Herb VC

Climber VC

Climber VC

Tree $\quad \mathrm{CO}$

Climber $\mathrm{CO}$

Tree EN

Shrub VU

Shrub CO

Shrub VC

Shrub CO

Shrub VC

Tree PL

Tree VU

Shrub CO

Tree PL

Tree $\quad \mathrm{CO}$

Shrub CO

Tree CO

Tree $\quad \mathrm{CO}$

Shrub VU

Tree $\quad \mathrm{CO}$

Tree VU

Shrub VC

Shrub VC

Tree $\quad \mathrm{CO}$

Tree $\mathrm{CO}$

Tree VU

Tree VU

Shrub VC 
M. JASHIMUDDIN, M. INOUE

Continue

\begin{tabular}{|c|c|c|c|c|c|}
\hline 37 & Melastomataceae & 1 & Melastoma malabathricum & Shrub & $\mathrm{VC}$ \\
\hline \multirow{4}{*}{38} & \multirow{4}{*}{ Meliaceae } & \multirow{4}{*}{4} & Aphanamixis polystachya & Tree & $\mathrm{CO}$ \\
\hline & & & Cedrela macrocarpa & Tree & $\mathrm{VU}$ \\
\hline & & & Cedrela toona & Tree & $\mathrm{VU}$ \\
\hline & & & Chickrassia tabularis & Tree & $\mathrm{VU}$ \\
\hline \multirow{13}{*}{39} & \multirow{13}{*}{ Moraceae } & \multirow{13}{*}{13} & Artocarpus chaplasha & Tree & $\mathrm{CO}$ \\
\hline & & & Artocarpus heterophyllus & Tree & PL \\
\hline & & & Artocarpus lacucha & Tree & VU \\
\hline & & & Ficus benghalensis & Tree & $\mathrm{CO}$ \\
\hline & & & Ficus clavata & Tree & $\mathrm{CO}$ \\
\hline & & & Ficus hispida & Tree & $\mathrm{VC}$ \\
\hline & & & Ficus lepidosa & Tree & $\mathrm{CO}$ \\
\hline & & & Ficus pyrifomis & Tree & $\mathrm{CO}$ \\
\hline & & & Ficus racemosa & Tree & $\mathrm{CO}$ \\
\hline & & & Ficus radicans & Climber & $\mathrm{CO}$ \\
\hline & & & Ficus religiosa & Tree & $\mathrm{VU}$ \\
\hline & & & Ficus semicordata & Tree & $\mathrm{VC}$ \\
\hline & & & Streblus asper & Tree & $\mathrm{VC}$ \\
\hline 40 & Musaceae & 1 & Musa sapientum & Herb & $\mathrm{VC}$ \\
\hline 41 & Myristicaceae & 1 & Myristica longifolia & Tree & EN \\
\hline \multirow{4}{*}{42} & \multirow{4}{*}{ Myrtaceae } & \multirow{4}{*}{4} & Psidium guajava & Tree & $\mathrm{VU}$ \\
\hline & & & Syzygium cumini & Tree & $\mathrm{VU}$ \\
\hline & & & Syzygium fruticosum & Tree & $\mathrm{VC}$ \\
\hline & & & Syzygium grande & Tree & $\mathrm{VU}$ \\
\hline 43 & Pandanaceae & 1 & Pandanus kaida & Tree & $\mathrm{CO}$ \\
\hline \multirow{2}{*}{44} & \multirow{2}{*}{ Phyllanthaceae } & \multirow{2}{*}{2} & Bischofia javanica & Tree & $\mathrm{VU}$ \\
\hline & & & Phyllanthus emblica & Tree & $\mathrm{CO}$ \\
\hline \multirow{6}{*}{45} & \multirow{6}{*}{ Poaceae } & \multirow{6}{*}{6} & Bambusa teres & $\begin{array}{l}\text { Bam- } \\
\text { boo }\end{array}$ & $\mathrm{CO}$ \\
\hline & & & Bambusa tulda & $\begin{array}{l}\text { Bam- } \\
\text { boo }\end{array}$ & $\mathrm{VC}$ \\
\hline & & & Dendrocalamus longispathus & $\begin{array}{l}\text { Bam- } \\
\text { boo }\end{array}$ & $\mathrm{VU}$ \\
\hline & & & Imperata arundinaceae & Grass & $\mathrm{VC}$ \\
\hline & & & Melocanna baccifera & $\begin{array}{l}\text { Bam- } \\
\text { boo }\end{array}$ & $\mathrm{VC}$ \\
\hline & & & Thysanolacana maxima & Shrub & $\mathrm{CO}$ \\
\hline 46 & Podocarpaceae & 1 & Podocarpus nerifolia & Tree & EN \\
\hline 47 & Pteridaceae & 1 & Pteris cretica & Fern & $\mathrm{VC}$ \\
\hline 48 & Rhamnaceae & 1 & Zizyphus mauritiana & Tree & PL \\
\hline \multirow{2}{*}{49} & \multirow{2}{*}{ Rubiaceae } & \multirow{2}{*}{2} & Hymenodictylon excelsum & Tree & $\mathrm{EN}$ \\
\hline & & & Paederia foetida & Climber & $\mathrm{CO}$ \\
\hline
\end{tabular}




\begin{tabular}{|c|c|c|c|c|c|}
\hline \multirow{2}{*}{50} & \multirow{2}{*}{ Rutaceae } & \multirow{2}{*}{2} & Citrus grandis & Tree & $\mathrm{CO}$ \\
\hline & & & Murray koengii & Shrub & VU \\
\hline 51 & Salicaceae & 1 & Flacourtia jangomas & Tree & $\mathrm{VU}$ \\
\hline 52 & Sapindaceae & 1 & Erioglossum edulis & Tree & VU \\
\hline 53 & Simaroubaceae & 1 & Ailanthus excelsa & Tree & VU \\
\hline 54 & Smilacaceae & 1 & Smilax roxburghiana & Climber & $\mathrm{VC}$ \\
\hline \multirow{2}{*}{55} & \multirow{2}{*}{ Solanaceae } & \multirow{2}{*}{2} & Solanum indicum & Shrub & $\mathrm{CO}$ \\
\hline & & & Solanum nigrum & Shrub & $\mathrm{CO}$ \\
\hline 56 & Sonneratiaceae & 1 & Duabanga grandiflora & Tree & VU \\
\hline 57 & Sterculiaceae & 1 & Pterygota alata & Tree & EN \\
\hline 58 & Theaceae & 1 & Schima wallicii & Tree & $\mathrm{VU}$ \\
\hline 59 & Verbenaceae & 1 & Lantana camara & Shrub & $\mathrm{VC}$ \\
\hline 60 & Zingiberaceae & 1 & Amomum subulatum & Shrub & $\mathrm{CO}$ \\
\hline Total & - & 163 & - & - & - \\
\hline
\end{tabular}

at increasing government revenue or extracting important natural resources combined with nationalization of forests, encouraging sedentary agriculture, privatization for long term horticulture or tree plantation, government sponsored population migration program or other development programs. Prior to the nationalization of forests, tribal people used to manage and use forest resources based on mutually agreed rules and regulations that had prevented forest encroachment by outsiders (Thapa \& Rasul, 2006). Experiences from CHT shows that privatization and government regulation envisioned by Hardin (1968) to solve the tragedy of commons problems have failed to reduce the problem of widespread deforestation and degradation of common lands, and to ensure effective management and conserve those resources customarily owned and maintained by the tribal communities (Rasul \& Thapa, 2005). However, common property systems that have survived through considerable periods of change identify small size, internal homogeneity, functioning local leadership and isolation from markets as important determinants of their endurance (Arnold, 1998). Due to population pressure and socio-political reasons VCF in the CHT are in stake of extinction. It is believed that a crucial factor towards long-term sustenance of common village forests is formal recognition of these areas, to secure use, access and tenure regimes (Tiwari, 2003). Existing norms, social capital, extent of dependence on forest, effective leadership are some other factors that influence collective action in resource management (Talwar \& Ghate, 2003).

It is clear that VCF are the only remaining forests in some parts of the CHT (Roy, 2000) that are enriched with more biodiversity than that of government forests and indigenous management of resources were sustaining a balance between exploitation and conservation (Baten et al., 2010; Adnan \& Dastidar, 2011). We found that VCF still contain dense forests containing rich biodiversity including rare plant and animal species. So, there is an urgent need to protect and manage these VCF from being degraded for the sake of indigenous people and the ecosystem as a whole. This is also important for Bangladesh being the party to the Convention on Biological Diver- sity (which is ratified on 5 June, 1992). Population pressure coupled with widespread resource destruction, livelihood insecurity, better market facilities, socio-political conditions, government policies and consistent disregard from the part of government regarding protection and management are placing major threats to the sustenance of VCF in the CHT. Sometimes it is also important to guard against internal inequities within the community based on gender, kinship, social status or otherwise that disrupt social cohesion leading to the abandonment of community efforts to manage the forests (Halim \& Roy, 2006) which may arise due to local elites laying claim to a disproportionate share of resources (Sunderlin, Hatcher, \& Liddle, 2008). Dependence of the community people on forests can also be considered as a factor of forest destruction particularly the VCF. At the same time the community people should be aware of the possible losses for the destruction of VCF. Realizing the facts some NGOs have initiated programs to protect and develop VCF and at the same time improving the livelihood of the community people to reduce their dependency on forests, namely, DANIDA and Arranyak Foundation involving some local NGOs like, Taungya, Biram, Humanitarian Foundation, Tah Zing Dong (Halim \& Roy, 2006; AF, 2010) as there is no government initiative in safeguarding these common forests. Several authors have highlighted the role of NGOs in maintaining and safeguarding common forests in CHT and elsewhere (Nath \& Inoue, 2008; Nath, Inoue, \& Pretty, 2010; Duthy \& Bolo-Duthy, 2003; Halim \& Roy, 2006). NGOs have added a new dimension in the forest management, which has ensured participation of the community people and protection of the vegetation (Zaman, et al., 2011). However, it is important for the government to come forward with policies and some rules and regulations in giving the tenure security to the indigenous community who are maintaining the VCF for long and also encourage other communities to maintain VCF around or near their homesteads with some financial and legal incentives. One option could be to devolve property rights and management authority to the community people specifying the number of families and size of the VCF with a community ini- 
tiated management plan regulating management of forest resources, access to the forests and equitable distribution of benefits among the community members as practiced in the Community Forestry program in Nepal (Wakiyama, 2004; Gautam et al., 2004; DoF, 2011; Adhikari et al., 2007; Acharya, 2002) and Joint Forest Management in India (Panigrahi, 2006; Behera \& Engel, 2006; Vemuri, 2008). Although, the government has adopted participatory forest management but due to bureaucratic attitude easy access of the poor habitants are restricted in many cases. It is observed that forest management in CHT is a classic example of the alienation of land and forests from indigenous people and the transfer of resources from poor to rich, local to outsider, periphery to centre (Rasul, 2007). As the indigenous people are very much dependent on the forests so the creation of alternative income generation opportunities is also very important to reduce their dependency on forests and thereby conserving the forests and biodiversity. To overcome these situations, the existing government forest policy, especially for CHT, needs major modification including legal devolution of power to the community people and allowing them freely manage small tracts of forests (around 100 ha) in or near their villages involving NGOs and other stakeholders as facilitators with acceptable benefit sharing agreements. Zaman et al. (2011) also suggested accommodating the NGOs, grass root organizations and general people in policy formulation, execution and evaluation of the program.

\section{Conclusion and Policy Recommendation}

VCF in the CHT undoubtedly play an important role in biodiversity conservation and as well as supporting daily necessities of the community people. However, population pressure combined with improved marketing facilities, ignorance, over exploitation, personal greed, tenure insecurity, faulty government policies regarding settlement of land and breakdown of the traditional systems exerting pressures on these VCF and the overall condition of these important biodiversity rich areas are degrading or shrinking in size and number gradually. In this situation there is an urgency to initiate efforts to manage these sustainably both from government and non-government (NGOs) initiatives. In general, government forest authority has no control over these forests and they failed to show their efficiency to manage forests sustainably in CHT or other parts of the country. However, the government can come up with new policies and legal instruments especially recognizing the traditional and customary resource rights of the indigenous communities in the CHT, acknowledging resource management system, providing tenure security, strictly banning the transfer of VCF land to individual or for settlement purposes that will ease the protecttion of VCF and will earn the thrust of the tribal communities, encouraging communities through legal and financial incentives in protecting these $\mathrm{VCF}$ or any other state owned forest areas solely for the conservation of biodiversity (only the indigenous species) with intensive management plan, resolving long lasting land related conflicts among indigenous communities, settlers and government authorities, and at the same time upholding the spirit of CHT Peace Accord 1997. NGOs showed their efficiency in maintaining biodiversity and safeguarding livelihood over the years, so they can be utilized to protect VCF in CHT. It is still not too late to initiate a coordinated effort for these VCF that will conserve the important biodiversity resources and provide essential supports to the community people and help reduce environmental degradation which is now an important global concern from both social and economic point of view. Lessons learned from this study will be useful for policymakers, planners, management and development officials for formulating effective community initiated forest management projects in Bangladesh and other developing countries.

\section{Acknowledgements}

We thank the Arranyak Foundation, Dhaka for largely financing the research. The authors also express their deep gratitude to the management of Humanitarian Foundation and Tah Zing Dong, two local NGOs implementing community based co-management projects to protect VCF in Bandarban Hill District, financed by Arranyak Foundation, for their kind help and co-operation during the field survey.

\section{REFERENCES}

Acharya, K. P. (2002). Twenty-four years of community forestry in Nepal. International Forestry Review, 4, 149-156. doi:10.1505/IFOR.4.2.149.17447

Adhikari, B., Williams, F., \& Lovett, J. C. (2007). Local benefits from community forests in the middle hills of Nepal. Forest Policy \& Economics, 9, 464-478. doi:10.1016/j.forpol.2005.11.002

Adnan, S., \& Dastidar, R. (2011). Alienation of the lands of indigenous peoples in the Chittagong Hill Tracts of Bangladesh. Dhaka/Copenhagen: Chittagong Hill Tracts Commission/International Work Group for Indigenous Affairs.

AF (2010). Conserving forests for the future: Annual report 2009. Dhaka: Arannayk Foundation. URL.

http://www.arannayk.org/docs/af annualreport 2009.pdf

Ali, M. E., \& Tsuchiya, T. (2002). Land rights of the indigenous people of the Chittagong Hill Tracts in Bangladesh: A historical analysis of policy issues. Fourth World Journal, 5, 63-79.

Arnold, J. E. M. (1998). Managing forests as common property: FAO Forestry Paper 136. Rome: Food and Agriculture Organization of the United Nations.

Azam, M., \& Sarker, T. (2011). Green tourism in the context of climate change towards sustainable economic development in the South Asian Region. Journal of Environmental Management and Tourism, $1,6-15$.

Banerjee, A. K. (2000). Devolving forest management in Asia-Pacific countries. In T. Enters, P. B. Durst, \& M. Victor (Eds.), Decentralization and devolution of forest management in Asia and the Pacific. RECOFTC Report 18, RAP Publication 2000/1, Bangkok.

Barkat, A., Halim, S., Poddar, A., Badiuzzaman, M., Osman, A., Khan, M. S., Rahman, M., Majid, M., Mahiyuddin, G., Chakma, S., \& Bashir, S. (2009). Socio-economic baseline survey of Chittagong Hill Tracts. Dhaka: Human Development Research Centre (HDRC)/Chittagong Hill Tracts Development Facility (CHTDF)/UNDP. URL. http://www.chtdf.org/chtdf_files/chtdf_documents/Publications/Stud y\%20Reports/Survey/Socio-economic_BaselineSurvey_CHT_\%20HD RC \%2008April09.pdf

Baten, M. A., Khan, N. A., Ahammad, R., \& Misbahuzzaman, K. (2010). Village common forests in Chittagong Hill Tracts, Bangladesh: Balance between Conservation and Exploitation. Dhaka: Unnayan Onneshan-The Innovators, 13.

Baumann, P. (2002). Improving access to natural resources for the rural poor: A critical analysis of central concepts and emerging trends from a sustainable livelihoods perspective. LSP Working Paper 1, Access to Natural Resources Sub-Programme, Livelihood Support Programme (LSP). Rome: Food and Agriculture Organization of the United Nations.

Behera, B., \& Engel, S. (2006). Institutional analysis of evolution of joint forest management in India: A new institutional economics approach. Forest Policy \& Economics, 8, 350-362. doi:10.1016/j.forpol.2005.08.006 
Berkes, F., Feeny, D., McCay, B. J., \& Acheson, M. J. (1989). The benefits of the commons. Nature, 340, 91-93.

doi: $10.1038 / 340091 \mathrm{a} 0$

Biswas, A. K. (1992). Forest management, environment and development in South Asia. Contemporary South Asia, 1, 249-258. doi:10.1080/09584939208719684

Chakma, B., Khisa, B. B., \& Chakma, S. (undated). Conflict into opportunities: Towards forest governance in Chittagong Hill Tracts (A case study from Bangladesh). Internal Displacement Monitoring Centre (IDMC). URL.

http://www.internal-displacement.org/8025708F004CE90B/(httpDoc uments)/6DF92D6FFC994A7DC12575F40061C235/\$file/B._Chakm a 3.1.pdf

Chowdhury, K. (2008). Politics of identities and resources in Chittagong Hill Tracts, Bangladesh: Ethnonationalism and/or indigenous identity. Asian Journal of Social Science, 36, 57-78. doi:10.1163/156853108X267567

Chowdhury, M. S. H., \& Miah, M. D. (2003). Housing pattern and food habit of the Mro-tribe community in Bangladesh: A forest dependence perspective. Journal of Forestry Research, 14, 253-258. doi:10.1007/BF02856841

CIFOR (2011). Community-based forest management key to success of REDD+. Center for International Forestry Research (CIFOR). URL (last checked 10 July 2011).

http://www.cifor.cgiar.org/mediamultimedia/newsroom/press-release s/press-releases-detail-view/article/238/community-based-forest-man agement-key-to-success-of-redd.html

Ciriacy-Wantrup, S. V., \& Bishop, R. C. (1975). "Common property" as a concept in natural resources policy. Natural Resources Journal, 15, 713-727.

DoF. (2011). Community forestry. Department of Forests, Government of Nepal. URL (last checked 23 October 2011).

http://www.dof.gov.np/index.php?option=com_content\&view=articl e\&id=95\&Itemid=121

Duthy, S., \& Bolo-Duthy, B. (2003). Empowering people's organizations in community based forest management in the Philippines: The community organizing role of NGOs. Annals of Tropical Research, 25, 13-27.

FAO (2011). State of the world's forests. Rome: Food and Agriculture Organization of the United Nations. URL. http://www.fao.org/docrep/013/i2000e/i2000e.pdf

Feeny, D., Berkes, F., McCay, B. J., \& Acheson, J. M. (1990). The tragedy of commons: Twenty-two years later. Human Ecology, 18, 1-19. doi:10.1007/BF00889070

FRA. (2010). Global forest resources assessment 2010: Main report. FAO Forestry Paper 163. Rome: Food and Agriculture Organization of the United Nations. URL. http://www.fao.org/docrep/013/i1757e/i1757e.pdf

Gautam, A. P., Shivakoti, G.P., \& Webb, E. L. (2004). A review of forest policies, institutions, and changes in the resource condition in Nepal. International Forestry Review, 6, 136-148. doi:10.1505/ifor.6.2.136.38397

Halim, S., \& Roy, R. D. (2006). Lessons learned from the application of human rights-based approaches in the indigenous forestry sector in the Chittagong Hill Tracts, Bangladesh: A case study of the village common forest project implemented by Taungya. URL. http://hrbaportal.org/wp-content/files/1233223431_8_1_1_resfile.pdf

Halim, S., Roy, R. D., Chakma, S., Tanchangya, S.B. (2007). Bangladesh: The interface of customary and state laws in the Chittagong Hill Tracts. In H. Leake (Ed.), Bridging the gap: Policies and practices on indigenous peoples' natural resource management in Asia. Chiang Mai: UNDP-RIPP/AIPP Foundation.

Halim, S., Roy, R. D., Chakma, S., \& Tanchangya, S. B. (undated). Natural resource management country studies: Bangladesh report. Regional Indigenous Peoples' Programme, United Nations Development Programme (UNDP-RIPP). URL.

http://www.snap-undp.org/elibrary/Publications/NRMBangladesh.pdf

Hardin, G. (1968). The tragedy of the commons. Science, 162, 12431248. doi: $10.1126 /$ science. 162.3859 .1243

Heltberg, R. (2001). Determinants and impact of local institutions for common resource management. Environment and Development Eco- nomics, 6, 183-208. doi:10.1017/S1355770X01000110

IPP (2011). BAN: Second Chittagong Hill Tracts Rural Development Project. Indigenous Peoples Plan (IPP). Dhaka: Ministry of Chittagong Hill Tracts Affairs and Asian Development Bank.

Islam, M. A., Marinova, D., Khan, M. H., Chowdhury, G.W., Chakma, S., Uddin, M., Jahan, I., Akter, R., Mohsanin, S., \& Tennant, E. (2009). Community Conserved Areas (CCAs) in Bangladesh. Dhaka: Wildlife Trust of Bangladesh.

Jamaluddin, M., Hassan, M. K., \& Miah, M. M. (2010). Identifying livelihood patterns of ethnic minorities and their coping strategies different vulnerabilities situation in Chittagong Hill Tracts Region, Bangladesh. Final Report CF\#7/08. Dhaka: National Food Policy Capacity Strengthening Programme (NFPCSP), USAID.

Khan, N. A., \& Khisa, S. K. (2000). Sustainable land management with rubber based agroforestry: A Bangladeshi example of uplands community development. Sustainable Development, 8, 1-10. doi:10.1002/(SICI)1099-1719(200002)8:1<1::AID-SD126>3.0.CO;2-C

Khisa, S. K. (1998). Ethno-botanical cultural background of ethnic communities in forest resource management in Chittagong Hill Tracts. In R. L. Banik, M. K. Alam, S. J. Pei, \& A. Rastog (Eds.), Applied ethnobotany (pp. 56-63). Chittagong: Bangladesh Forest Research Institute.

Lasimbang, J. (2006). Natural resource management country studies. Regional Synthesis Paper. Regional Indigenous Peoples' Programme, UNDP. URL.

http://www.snap-undp.org/elibrary/Publications/NRMRegionalSynth esisPaper.pdf

Mahapatra, L. K. (1997). Parameters of forest policy for tribal development. In P. M. Mohapatra, \& P. C. Mohapatro (Eds.), Forest management in tribal areas: Forest policy and peoples participation (pp. 26-42). New Delhi: Concept Publishing Company.

McKean, M. A., \& Ostrom, E. (1995). Common property regimes in the forest: Just a relic from the past. Unasylva, 180, 3-15.

Miah, M. D., \& Chowdhury, M. S. H. (2004). Traditional forest utilizetion practice by the Mro tribe in the Bandarban region, Bangladesh. Schweiz Z Forstwes, 155, 65-70. doi:10.3188/szf.2004.0065

Mjanger, G. (2008). The land is not ours: Alienation of land rights of the Jumma in the Chittagong Hill Tracts, Bangladesh. Master's Thesis, Hague: Institute of Social Studies.

Mohiuddin, M., \& Alam, M. K. (2011). Opportunities of traditional knowledge in Natural resource management experience from Chittagong Hill Tracts, Bangladesh. Indian Journal of Traditional Knowledge, 10, 474-480.

Muhammed, N., Koike, M., \& Haque, F. (2008) Forest policy and sustainable forest management in Bangladesh: An analysis from national and international perspectives. New Forests, 36, 201-216. doi:10.1007/s11056-008-9093-8

Nasreen, J., \& Togawa, M. (2002). Politics of development: 'PahariBengali' discourse in the Chittagong Hill Tracts. Journal of International Development and Cooperation, 9, 97-112.

Nath, T. K., \& Inoue, M. (2008). The upland settlement project of Bangladesh as a means of reducing land degradation and improving rural livelihoods. Small-Scale Forestry, 7, 163-182. doi: 10.1007/s11842-008-9048-0

Nath, T. K., \& Inoue, M. (2009). Forest based settlement project and its impact on community livelihood in Chittagong Hill Tracts, Bangladesh. International Forestry Review, 11, 394-407. doi:10.1505/ifor.11.3.394

Nath, T. K., Inoue, M., \& Chakma, S. (2005a). Shifting cultivation (jhum) in the Chittagong Hill Tracts, Bangladesh: Examining its sustainability, rural livelihood and policy implications. International Journal of Agricultural Sustainability, 3, 130-142. doi:10.1080/14735903.2005.9684751

Nath, T. K., Inoue, M., \& Hla Myant, M. (2005b). Small-scale agroforestry for upland community development: A case study from Chittagong Hill Tracts, Bangladesh. Journal of Forest Research, 10, 443452. doi: $10.1007 / \mathrm{s} 10310-005-0171-\mathrm{x}$

Nath, T. K., Inoue, M., \& Pretty, J. (2010). Formation and function of social capital for forest resource management and the improved livelihoods of indigenous people in Bangladesh. Journal of Rural and Community Development, 5, 104-122. 
Nayak, P. K. (2002). Community-based Forest Management in India: the Issue of Tenurial Significance. The 9th Biennial Conference of the IASCP (International Association for the Study of Common Property), Victoria Falls, 17-21 June 2002.

Nishat, A., \& Biswas, S. (2005). Community-based restoration of degraded tropical hill forests: Experiences from Krykhong Para, Chittagong Hill Tracts, Bangladesh. Bulletin 16: 1-11. Jaipur/New Delhi: National Institute of Ecology.

Panigrahi, R. (2006). Democratization of Forest governance: Myths and realities. The Eleventh Biennial Conference of the International Association for the Study of Common Property, Bali, 19-23 June 2006.

Rahman, M. A. (2005). Chittagong Hill Tracts peace accord in Bangladesh: Reconciling the issues of human rights, indigenous rights and environmental governance. Journal of Bangladesh Studies, 7, 46-58.

Rahman, S. A., Rahman, M. F., Codilan, A. L., \& Farhana, K. M. (2007). Analysis of the economic benefits from systematic improvements to shifting cultivation and its evolution towards stable continuous agroforestry in the upland of Eastern Bangladesh. International Forestry Review, 9, 536-547.

Rahman, S. A., Rahman, M. F., \& Sunderland, T. (2011). Causes and consequences of shifting cultivation and its alernative in the hill tracts of eastern Bangladesh. Agroforestry Systems, 84, 141-155. doi:10.1007/s10457-011-9422-3

Rasul, G. (2005). State policies and land use in the Chittagong Hill Tracts of Bangladesh. IIED Gatekeeper Series 119. London: International Institute for Environment and Development.

Rasul, G. (2007). Political ecology of the degradation of forest commons in the Chittagong Hill Tracts of Bangladesh. Environmental Conservation, 34, 153-163. doi:10.1017/S0376892907003888

Rasul, G., \& Karki, M. (2006). Political ecology of degradation of forest common in the Chittagong Hill Tracts of Bangladesh. The Eleventh Biennial Conference of the International Association for the Study of Common Property, Bali, 19-23 June 2006.

Rasul, G., \& Thapa, G. B. (2003). Shifting cultivation in the mountains of south and southeast Asia: Regional patterns and factors influenceing the change. Land Degradation \& Development, 14, 495-508. doi:10.1002/ldr.570

Rasul, G., \& Thapa, G. B. (2005). State policies, praxies and land-use in the Chittagong Hill Tracts of Bangladesh. IIED Working Paper. London: International Institute for Environment and Development. URL. http://hdl.handle.net/10535/6189

Rasul, G., \& Thapa, G. B. (2006). Financial and economic suitability of agroforestry as an alternative to shifting cultivation: The case of the Chittagong Hill Tracts, Bangladesh. Agricultural Systems, 91, 29-50. doi:10.1016/i.agsy.2006.01.006

Rasul, G., Thapa, G. B., \& Zoebisch, M. A. (2004). Determinants of land-use changes in the Chittagong Hill Tracts of Bangladesh. Applied Geography, 24, 217-240. doi:10.1016/j.apgeog.2004.03.004

Roy, R. C. K. (2000). Land rights of the indigenous peoples of the Chittagong Hill Tracts, Bangladesh. Copenhagen: International Work Group for Indigenous Affairs (IWGIA).

Roy, R. D. (1998). Land rights: Land use and indigenous peoples in the Chittagong Hill Tracts. In P. Gain (Ed.), Bangladesh: Land, Forest and Forest People (pp. 53-118). Dhaka: Society for Environment and Human Development (SEHD).

Roy, R. D. (2002). Land and forest rights in the Chittagong Hill Tracts, Bangladesh. ICIMOD Talking Points 4/02. Kathmandu: International Centre for Integrated Mountain Development.

Roy, R. D. (2004) Challenges for juridical pluralism and customary laws of indigenous peoples: The case of the Chittagong Hill Tracts, Bangladesh. Arizona Journal of International \& Comparative Law, 21, 113-182.

Roy, R. D., \& Halim, S. (2002). Valuing Village commons in forestry. Indigenous Perspectives, 5, 9-38.

Roy, R. D., Hossain, S., Guhathakurta, M. (2007). Access to justice for indigenous peoples in Bangladesh: Case study. Towards Inclusive Governance Promoting Participation of Disadvantaged Groups in Asia-Pacific. Bangkok: UNDP Regional Indigenous Peoples' Programme (RIPP)/UNDP.

Ruiz-Pe'rez, M., Almeida, M., Dewi, S., Costa, E. M. L., Pantoja, M. C., Puntodewo, A., Postigo, A. A., \& de Andrade, A. G. (2005). Conservation and development in Amazonian extractive reserves: The case of Alto Jurua. Ambio, 34, 218-223.

Saha, P. S. (2010). Parbattya Chattagramer Mouza Ban: Prachin Praggyar Arek Rup. In P. Gain (Ed.) Dharitri, 11th issue, an occasional SEHD magazine (Bangla). Dhaka: Society for Environment and $\mathrm{Hu}-$ man Development (SEHD). URL. http://www.sehd.org/publications/magazines/dharitri

Stocks, A., McMahan, B., \& Taber, P. (2007). Indigenous, colonist and government impacts on Nicaragua's Bosawas Reserve. Conservation Biology, 21, 1495-1505.

Sunderlin, W. D., Hatcher, J., \& Liddle, M. (2008). From exclusion to ownership? Challenges and opportunities in advancing forest tenure reform. Washington DC: Rights and Resources Initiative.

Talwar, D. M., \& Ghate, R. (2003). Community-initiated forest management without land tenure: How feeble, how strong? A study of three villages from central India. The Conference on Politics of the Commons: Articulating Development and Strengthening Local Practices, Chiang Mai, 11-14 July 2003. URL.

http://hdl.handle.net/10535/243

Thapa, G. B., \& Rasul, G. (2006). Implications of changing national policies on land use in the Chittagong Hill Tracts of Bangladesh. Journal of Environmental Management, 81, 441-453. doi:10.1016/j.jenvman.2005.12.002

Tiwari, S. (2003). Chittagong Hill Tracts: A preliminary study on gender and natural resource management. Ottawa: IDRC. URL. http://hdl.handle.net/10625/30490

Uddin, M. A. (2008). Displacement and destruction of ethnic people in Bangladesh. Canadian Social Science, 4, 16-24.

van Schendel, W., Mey, W., \& Dewan, A. K. (2001). The Chittagong Hill Tracts: Living in a Boarderland. Dhaka: The University Press Ltd.

Vemuri, A. (2008). Joint Forest Management in India: An unavoidable and conflicting common property regime in natural resource management. Journal of Development and Social Transformation, 5, 8190 .

Wakiyama, T. (2004). Community forestry in Nepal: A comparison of management systems between indigenous forestry and modern community forestry. In: K. Harada, \& M. Nanang (Eds.), Policy Trend Report 2004 (pp. 1-20). Hayama: Institute for Global Environmental Strategies (IGES)

White, A., \& Martin, A. (2002). Who owns the world's forests? Forest tenure and public forests in transition. Washington DC: Forest Trends.

Zaman, S., Siddiquee, S. U., Faruq, M. A. A., Pramanik, M. R., Katoh, M. (2011). Reckoning Participatory Forest Management in Bangladesh: Study from Its Implementation Perspective. Journal of Agricultural Science, 3, 233-239. 